\title{
Reanalysis of marine-coastal indicators assessed by national and multi- national organizations for the integrated coastal zone management ${ }^{*}$
}

\author{
Raquel Dezidério Souto ${ }^{\circledR}$, a
}

\begin{abstract}
The progressive occupation of coastal zones led to consolidation of the Integrated Coastal Zone Management (ICZM) as a shared management process that aims to improve population life quality, to conserve biological diversity and coastal productivity. This ICZM view follows the premises of sustainable development, established in 1992 by the United Nations Conference on Environment and Development - environmental conservation, economic growth and social equality. In this Conference, countries were invited to produce indicator systems, as a follow-up towards sustainable development. At world level, the Intergovernmental Oceanographic Commission (IOC) prepared in 2006 a handbook of indicators to support the ICZM, titled $A$ Handbook for Measuring the Progress and Outcomes of Integrated Coastal and Ocean Management (ICAM Handbook), incorporating socioeconomic, ecological and political dimensions as the base to analyzis. The present work reanalyzes marinecoastal areas indicators related to the ICZM, included by ten selected organizations in its official publications and websites about sustainability (or sustainable development). Seven sources are national: SayDS (Argentina), INE (Spain), INEGI (Mexico), DEFRA (United Kingdom), IBGE (Brazil), APA (Portugal) and Statistics Canada (Canada); and three, multinational - The GEO Project, REDESA and ILAC. The analysis has the list of ecological indicators suggested by the ICAM Handbook as a reference. The results showed that a few number of indicators are related to marine-coastal areas (less than 15\%), giving the total number of indicators for each analyzed source. Most of the ecological indicators suggested by the ICAM Handbook are not considered by the selected organizations in its systems of sustainability indicators. The research aims to contribute to the improvement of the sustainability indicators systems, especially those maintained by the IBGE in Brazil, and to alert researchers and policy-makers to the importance of the natural environment as essential to the support of life, and to the conservation of biological diversity and productivity in marine-coastal areas.
\end{abstract}

Keywords: sustainable development, integrated coastal zone management, marine environment, indicators.

\section{RESUMO}

Reanálise dos indicadores marinhos e costeiros para gestão integrada da zona costeira, contemplados por organizações nacionais e multinacionais.

A progressiva ocupação de zonais costeiras levou à consolidação do Gerenciamento Costeiro Integrado (GCI) como um processo de gestão compartilhada que visa a melhoria da qualidade de vida da população e a conservação da diversidade biológica e da produtividade costeiras. Essa visão de GCI segue as premissas do desenvolvimento sustentável, estabelecidas na Conferência das Nações Unidas em Ambiente e Desenvolvimento, realizada em 1992 no Rio de Janeiro: conservação ambiental, crescimento econômico e igualdade social. Nessa mesma conferência, os países foram incentivados à produção de

(a) Corresponding author to whom correspondence should be addressed.

${ }^{\text {a }}$ Federal University of Rio de Janeiro, Center of Mathematics and Natural Sciences, Institute of Geosciences, Department of Geography, Postgraduate Program in Geography (PPGG/ UFRJ). Av. Athos da Silveira Ramos, 274, Cidade Universitária, Rio de Janeiro, RJ, Brazil. e-mail: <raquel.deziderio@gmail.com>

* Submission: 5 JUL 2014; Peer review: 6 AUG 2014; Revised: 1 DEC 2014; Accepted: 7 DEC 2014; Available on-line: 9 DEC 2014

This article contains supporting information online at http://www.aprh.pt/rgci/pdf/rgci-535_Souto_Supporting-Information.pdf
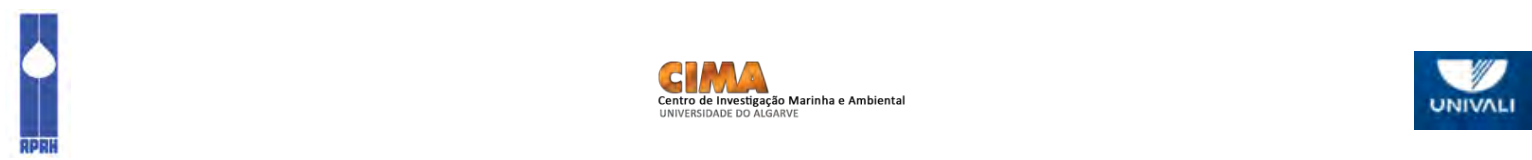
sistemas de indicadores, como forma de acompanhamento do rumo ao desenvolvimento sustentável. Em nível mundial, a Comissão Oceanográfica Intergovernamental elaborou em 2006 um manual de indicadores para apoio ao GCI, que inclui as dimensões socioeconômica, ecológica e política como base de análise, intitulado: "Manual para Mensuração do Progresso e dos Resultados do Gerenciamento Oceânico e Costeiro Integrados" (em inglês: "A Handbook for Measuring the Progress and Outcomes of Integrated Coastal and Ocean Management"), adiante referido como Manual ICAM. O presente trabalho tem como objetivo reavaliar indicadores marinhos costeiros relacionados com o GCI, incluídos por dez organizações selecionadas, nas suas publicações e websites oficiais sobre sustentabilidade (ou desenvolvimento sustentável). Sete fontes de dados são nacionais: SayDS (Argentina), INE (Espanha), INEGI (México), DEFRA (Reino Unido), IBGE (Brasil), APA (Portugal) e Statistics Canada (Canada); e três multinacionais: Projeto GEO, REDESA e ILAC. A análise tem a lista de indicadores ecológicos sugeridos pelo Manual ICAM como referência. A partir dos resultados, observou-se que, do total de indicadores de cada uma das dez fontes analisadas, há poucos indicadores relacionados às áreas costeiras e marinhas, com percentuais que não chegam a 15\%. Grande parte dos indicadores ecológicos sugeridos no Manual ICAM não são considerados nas fontes analisadas. $O$ trabalho visa contribuir para o aperfeiçoamento dos sistemas de indicadores de sustentabilidade, especialmente aquele mantido no Brasil pelo IBGE, e alertar aos pesquisadores e tomadores de decisão para a importância do meio natural como essencial ao suporte à vida e à conservação da diversidade biológica e da produtividade em áreas costeiras e marinhas.

Palavras chaves: desenvolvimento sustentável, gerenciamento costeiro integrado, ambientes costeiro e marinho, indicadores.

\section{Introduction}

The United Nations Conference on the Environment and Development (UNCED), held in Rio de Janeiro, dated on 1992, encouraged the participating countries to produce indicators to monitor their progress towards sustainable development, which is understood as economic growth coupled with environmental conservation and social equality.

It is noteworthy that in 1996, the Group of Experts on Scientific Aspects of Marine Protection (GESAMP) incorporated this vision that reconciles economic growth with environmental conservation and quality of life into the definition of the ICZM process: The goal of ICM is to improve the quality of life of human communities who depend on coastal resources while maintaining the biological diversity and productivity of coastal ecosystems. Thus, the ICM process must integrate government with the community, science with management, and sectoral with public interests in preparing and implementing actions that combine investment in development with the conservation of environmental qualities and functions. (GESAMP, 1996: iv)

Some researchers reaffirm the importance of the inclusion of at least three of the dimensions (environmental, economic and social) included in the sustainable development strategy, in the treatment of some coastal issues (Malone et al., 2014; Ye et al., 2014; Cooper, 2011; Gallagher, 2010; Peng et al., 2006; Pickaver et al., 2004; Shi et al., 2004; Polette \& Silva, 2003; Vandermeulen, 1998; Thia-Eng et al., 1997).

In Europe, the progress of implementation of the ICZM was evaluated by Pickaver et al. (2004), that showed the absence of an ICZM strategy, which includes the marine environment and that "has been produced which takes into account both the interdependency and disparity of natural processes and human activities" (Pickaver et al., 2004: 456). In the other hand, the ev- aluated strategies incorporate "the precautionary principle and an ecosystems approach, and (...) treats coastal areas as distinct and separate entities" (Pickaver et al., 2004: 456).

The importance of a holistic and integrated view in the analysis of the ICZM aspects is highlighted by Ye et al. (2014: 113), that argue that "the linkages and interdependencies of socio-economic, governance and coastal environmental dynamics have been rarely analyzed through evaluation".

Thia-Eng et al., (1997) describe the necessity of an integrated vision in the adoption of a strategy to the prevention and management of marine pollution and the rapid economic development in Xiamen, China. The same authors list the issues that have to be included in the environmental profile of the coast of Xiamen (ThiaEng et al., 1997: 239). Notes that there is an integration between the natural environment and the anthropogenic activities:

- Natural environment and its relation to development

- Marine resources and their development status

- Urban socioeconomics and status of ecological environment

- Status of coastal water quality

- Characteristics of marine ecosystems problems

- Status of marine environmental legislation

- Status of marine environmental management

In other work, dated on 2006, Chinese researchers investigate the socioeconomic benefits of the ICZM, using the improvements in the ICZM process in Xiamen (China) as a case study. Conclusions show that the obtained results demonstrate the improvement of the ICZM process in Xiamen is contributing to an economic development with nature conservancy of the region: (...) indicate that the ICM program in Xiamen has led to an impressive increase in net socioeconomic 
benefit from its marine sectors. The difference in the present values of total net benefit from 1997 to 2001 between the two policy regimes amounts to around 9 billion yuan. (...) The efforts to improve environmental quality and to conserve natural resources have resulted in a notable increase in environmental benefits. Furthermore, various external costs have declined in the Xiamen area. (Peng et al., 2006: 107)

Cheong (2008: 1090) indicates the importance of the dissolution of the limits between natural and social scientists in order to achieve a new direction in coastal management, which can be obtained through the sustainability science, which has emerged out of this interdisciplinary, (...) combining the areas of sustainable development and environmental science".

Ignacy Sachs (1990; 2002), a recognised Polish ecosocioeconomist, proposed eight dimensions for represent the sustainability: social, economic, ecological, territorial (before named, geographical), cultural, environmental, national politics and international politics. These dimensions can be combined when using the systems approach, which was borned with Ludwig von Bertalanffy (2006) in the Biological Sciences and spreads to many others scientific areas, until arrive to the environmental systems modelling, which is frequently used in the resolution of various types of environmental and socioeconomic problems (Christofoletti, 2010).

Shi et al. (2004: 336) argue that the systems approach has to be used to ensure the sustainable development of the coastal zone and that the national sustainability indicator system developed to Shangai municipality (and Chong Ming Islands), China, includes five sub-systems: survival, development, environment, social and intelligence supporting systems. In the same way, Gallagher (2010) defends the adoption of the management systems approach in order to achieve the coastal sustainability. The same author affirms that the ICZM plans and processes are based in the three golden principles of the sustainable development: sustainable economic growth, natural conservancy, and social equality.

Taussik (2007: 612) shows that the ICZM process in development in England is using the spatial planning approach, in order to ensure the sustainable balanced development of the European territory which respects its diversity. The same author explains that spatial planning is a term that can be applicable in a wider way, in other words, referring to aspects observed in a spatial or geographical dimension. The tools that use this approach frequently include zoning techniques and temporal controls.

For example, still according to Taussik (2007: 612), with respect to the marine-coastal areas, the following issues have a spatial dimension: new development, na- ture conservation, coastal defence and shoreline management; the regulation of minerals on and off shore; and fisheries. All these activities and related interests can cause conflicts and the ICZM is strategically important to resolve the conflicts present in coastal regions, in order to promote the proper management of their natural resources, as highlighted by Asmus et al. (2006: 52, our translation): The integrated coastal management arose from the need to manage the natural resources of the coastal zone in a sustainable manner. These regions have great commercial, industrial and touristic interest. Hence, the depletion of natural resources becomes evident in several respects, such as increased urban and industrial population (compared to the cluster population), overfishing, massive exploitation of mineral resources, among other equally important issues. The Integrated Coastal Management can be defined as a continuous and dynamic process by which decisions and actions are made for the sustainable use, development and protection of coastal areas and maritime resources.

The global increase of coastal population density, development of various industrial plants and port facilities, hotel network and fishing activity expansion, require determining whether the sustainability indicator systems maintained by national and multinational organizations incorporate all aspects of coastal and marine areas, taking into account all parameters and indicators listed. The health of coastal ecosystems and the population should be closely monitored to allow effective measures that can be taken to safeguard natural resources and individuals.

Seven countries with consolidated and internationally recognized official statistics agencies and which have developed their own sustainability (or sustainable development) indicator systems (or lists), were also included in the analysis. Among them there are four American institutions:

- Argentina - Secretariat of Environment and Sustainable Development (Spanish acronym: SayDS);

- Brazil - Brazilian Institute of Geography and Statistics (Portuguese acronym: IBGE);

- Mexico - National Institute of Statistics, Geography and Informatics (Spanish acronym: INEGI); and

- Statistics Canada (Canada);

and three European institutions:

- Spain - National Statistics Institute (Spanish acronym: INE);

- Portugal - Portuguese Environment Agency (Portuguese acronym: APA); and

- United Kingdom - Department for Environment, Food and Rural Affairs (English acronym: DEFRA). 
Three multinational initiatives were also selected because of its international recognition and, sometimes, because it corresponds to the region of which Brazil is part:

- Latin American Network of Experts on Social and Environmental Statistics in Latin America and the Caribbean (Spanish acronym: REDESA);

- Caribbean Initiative for Sustainable Development (Spanish acronym: ILAC); and

- Global Environment Outlook Project (GEO Project).

The Canadian National Round Table on the Environment and the Economy (NRTEE), a committee of experts, which function as an independent policy advisory agency to the Government of Canada, was established in 1988. The NRTEE report, dated on 2003 and titled The State of the debate on the Environment and the Economy: Environmental and Sustainable Development Indicators for Canada, was prepared with the cooperation of the Statistics Canada and the Environment Canada. Economic indicators included in this report are supplemented by indicators related to the human capital and the natural capital (NRTEE, 2003).

According to the natural capital model, the condition of sustainability is the maintenance over time of a stock or natural capital assets (or the total stock of capital artificial, natural and human) (Martínez, 2001). The indicators related to the human capital presents in the cited NRTEE report adopts metrics referred to the socioeconomic dimension (NRTEE, 2003) and, in the same way, following the strategy for the conservation of the stocks, in order to achieve the sustainability.

The Argentinean SayDS, the Brazilian IBGE, and the Mexican INEGI follow the guidelines of the regional project of the Comisión Económica para América Latina y el Caribe (CEPAL) (in English: Economic Commission for Latin America and the Caribbean, ECLAC), titled Evaluación de la Sostenibilidad en América Latina y el Caribe (in English: Sustainability Assessment in Latin America and the Caribbean) (Spanish acronym, ESALC).

The first consultative meeting of the ECLAC, with representatives of countries, was held in Santiago, Chile, dated November 29, 2001, reported in the Informe del Seminario Indicadores de Desarrollo Sostenible en América Latina y el Caribe (CEPAL, 2001). This ECLAC project follows the view of the socioecological model, a holistic approach, which consider two components: one, human, and other, ecological (CEPAL, 2001). This model follows the strong sustainability, concept in which different types of capital are not necessarily interchangeable (Gallopín, 2003).

Three European national organizations, the Spanish INE, the Portuguese APA and the DEFRA, from the United Kingdom, follow the European Union Sustain- able Development Strategy (EU-SDS), published in the report titled A Sustainable Europe for a Better World: A European Union Strategy for Sustainable Development, published by the Commission of the European Communities (EC, 2001).

The EU-SDS follows the sustainable development vision, present in official documents derivate from the United Nations Conference on Environment and Development (UNCED), also known as the Rio Summit, Rio Conference, and Earth Summit. According with this vision, the economic growth has to be accompanied by the environmental conservation and the social equality, in order to achieve the sustainable development.

All three selected multinational initiatives (REDESA, ILAC and Geo Project) also follow the recommendations of the UNCED, dated on 1992.

REDESA was created in 2001 by the Division of Statistics and Economic Projections of ECLAC to promote and strengthen the production of social and environmental statistics in the countries of the region. REDESA also acts as a coordinating organization and holding meetings with representatives of the countries concerned to improve the methodology for the collection and processing of data and encouraging the exchange of information and experiences among experts and institutions.

ILAC was proposed by the Forum of Ministers of Environment of Latin America and the Caribbean during the Johannesburg Summit, held by the United Nations in South Africa, in 2002. ILAC objectives are similar to REDESA, but it focuses more specifically on the institutional arrangements, as well as financial and political mechanisms to implement Agenda 21 in the region.

Initiated in 1995 by the United Nations Environment Program (UNEP), the GEO Project aims to meet the recommendations of Agenda 21, regarding the formulation of indicators for assessing the progress towards sustainable development.

Although these organizations follow the United Nations or regional strategies to reach the sustainable development, the list of indicators formulated and maintained by them have different configurations, regarding the aspects: objectives; conceptual model; form of development and disclosure of the indicator system; architecture; selection criteria; geographical coverage and how the indicators are presented (on press reports, on the Internet and on others medias) (Souto, 2011).

Regarding on the indicators schemes applied to the marine-coastal areas and that follow the three sustainable development principles, titled A Handbook for Measuring the Progress and Outcomes of Integrated Coastal and Ocean Management (hereinafter, ICAM Handbook) is the only intergovernmental document that guides the development of indicators to support ICZM. 
The ICAM Handbook was published by the Intergovernmental Oceanographic Commission (IOC), with the overall goal of contributing to the sustainable development of coastal and marine areas by promoting a measurable and adaptable, results-oriented approach to coastal management (IOC, 2006).

To meet this goal, the ICAM Handbook presents a wide range of ecological and socioeconomic indicators and metrics for assessing the ICZM process itself, providing a framework for the countries to adopt and adapt according to their regional characteristics (IOC, 2006). The ICAM Handbook also describes eight country case studies, including results and lessons gained from these experiences. Thus, the ICAM Handbook is considered an appropriate reference for sustainability assessments in coastal and marine areas as it covers the main topics of sustainable development (environmental, social, economic and political-institutional) and proposes to use indicators to assist the diagnosis and monitoring of the ICZM process, given the complex reality of coastal zones worldwide, which aggregate a wide variety of resources, types of use, stakeholders, interests and conflicts.

Ye et al. (2014: 113) argue that the ICAM Handbook is an useful reference, but the same authors alert, citing other authors, that there are still no widely accepted methodologies or common criteria for assessing ICM performances due to the complexity and heterogeneity of assigned ICM programmes in different regions (...). However, these authors also argue that the ICAM Handbook adopts the holistic and integrated vision (Ye et al., 2014: 113). It functions like a suggestive list of indicators, parameters and aspects to be considered in the moment of formulation of the ICZM indicators in the three levels of approach: local, regional and national.

The present work reanalyzes marine-coastal indicators related to the ICZM, included by the ten selected organizations in its official reports and websites about sustainability (or sustainable development). The analysis used the list of ecological indicators suggested by the ICAM Handbook as a reference (IOC, 2006). In the results, this work presents the main themes and the gaps, related to the marine-coastal areas, present in the analyzed sources. Additionally, this work aims to contribute with others producers of official statistics, highlighting the importance of the marine-coastal indicators to improve the ICZM processes in its countries.

Specifically for the official publication published by the IBGE, titled Indicadores de Desenvolvimento Sustentável: Brasil (in English: Sustainable Development Indicators: Brazil), this work seek also to contribute to its improvement, by suggesting parameters related to marine-coastal areas, which should be included in this publication.

\section{Material and methods}

The sustainability indicators included in the ten analyzed sources (official reports and websites) of national and multinational organizations, selected for this work, were compared with the list of ecological indicators presented in the ICAM Handbook (IOC, 2006, p.38), adopted as reference, in order to evaluate qualitatively what are the issues included in the analysed publications. A survey of the parameters used by each selected organization that have specific relevance to the marinecoastal areas was performed, and the results are presented in tables, which demonstrate the issues related to marine-coastal included by them.

The indicators from the national level were surveyed from the sources expressed at Supporting Information.

\section{Results and discussion}

The marine-coastal areas are under-represented in all the analyzed lists (or systems) of indicators. Table 1 presents the result of comparison between the organizations on the number of ecological indicators (absolute and approximate percentage) related to marine-coastal areas, as noted in the sources consulted; and yet, the total indicators contained in each observed source.

It is noteworthy that the DEFRA publication, from United Kingdom, which has the highest number of indicators (124 in total), has the lowest percentage of participation of marine-coastal areas (about $0.8 \%$ ). On the other hand, the multinational GEO Project, with the lowest number of indicators (21 in total), has the highest percentage (about 14.3\%) of indicators related to the marine-coastal areas. Among national initiatives, IBGE has the largest percentage (5.5\%) and DEFRA has the lowest percentage of participation of marine-coastal areas $(0.8 \%)$. There is no visible difference between sources from American countries and from European countries. And there is no difference also between countries considered on economic development or economically developed. Thus, the representation of the marine-coastal areas in the indicators schemes for the sustainability (or the sustainable development) seems to be independent of the economic development level and the geographic localization of the country.

Table 2 presents the indicators related to the marinecoastal areas, according to the analyzed sources. Most of the indicators related to marine-coastal areas, included in the analyzed sources, are related to fishing activity, but the parameters are distinguished, according to the subject (e.g., operationalization of the fishing activity, volume of fish production, environmental and sustainability aspects of the fishing activity). The ICAM Handbook presents the indicator of incidental mortality (by catch), which is essential for the conservation of 
Table 1 - Comparison between organizations. Absolute numbers and percentage of indicators related to the marine-coastal areas and total number of indicators listed.

Tabela 1 - Comparação entre organizações. Números absolutos percentuais de indicadores relacionados às áreas costeiras e marinhas e número total de indicadores listados.

\begin{tabular}{|c|c|c|c|c|c|c|c|c|c|c|}
\hline Indicators & 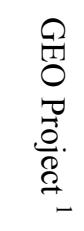 & 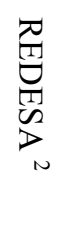 & $\stackrel{F}{2}$ & 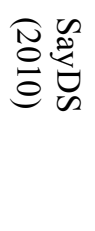 & 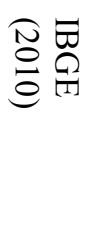 & 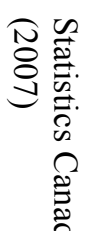 & $\begin{array}{l}\text { 응 } \\
8 \\
\varrho\end{array}$ & 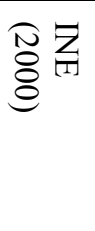 & 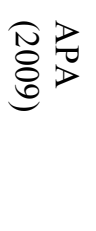 & 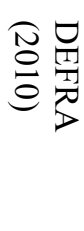 \\
\hline Total number of indicators listed & 21 & 87 & 54 & 72 & 55 & 73 & 113 & 121 & 59 & 124 \\
\hline $\begin{array}{l}\text { Number of indicators related to the marine- } \\
\text { coastal areas }\end{array}$ & 3 & 5 & 1 & 2 & 3 & 1 & 2 & 3 & 2 & 1 \\
\hline $\begin{array}{l}\text { Approximate percentage }(\%) \text { of indicators } \\
\text { related to the marine-coastal areas }\end{array}$ & 14.3 & 5.7 & 1.8 & 2.8 & 5.5 & 1.4 & 1.8 & 2.5 & 3.4 & 0.8 \\
\hline
\end{tabular}

GEO Data Portal/GEO Core Indicators (http://geodata.grid.unep.ch/extras/indicators.php).

${ }^{2}$ CEPALSTAT (http://www.cepal.org/en/datos-y-estadisticas).

${ }^{3}$ UNEP (2005).

fish stocks, but has not been included in the indicators set of any selected organization.

Table 2 also reveals that only Argentinian and Portuguese sources consider biomass indicators. The ICAM Handbook suggests a number of other production and reproduction indicators, which should be considered by the organizations: quality of habitats, secondary productivity, stages of life, reproductive parameters, average generation time and spawning survival rates.

Regarding the load of pollutants in coastal and marine areas, Statistics Canada considers the estimated total load of phosphorus, while Spanish INE, the mercury concentrations in fish and shellfish/ molluscs. The ICAM Handbook suggests monitoring the levels of pollutants and contaminants in the water and not just the bioaccumulation of toxic compounds, as well as the diseases and abnormalities of the species.

Swimming suitability, an indicator considered only by the Brazilian IBGE, is covered in the ICAM Handbook, under the subject "Water Quality".

Surprisingly, the resident population of coastal areas is considered only by the Brazilian IBGE and the Mexican INEGI. The distinction that must be made is that the index adopted in Brazil follows the absolute values of the resident population while Mexico monitors population growth. In the ICAM Handbook, this indicator appears in the list of socioeconomic indicators, but it is inserted in this survey to show that few of the evaluated organizations consider important to monitor the population in coastal areas.
The urbanization of the coastal areas grows continuously around the world, given the facilities for maritime trade, the attraction for the coastal environmental services and other reasons. It becomes, therefore, necessary to consider the coastal population indicator in sustainability (or sustainable development) indicators schemes of countries that have maritime boundary since the pressure of intense human occupation on these areas often leads to environmental problems.

The GEO Project presents "Change in glacial mass" indicator, which is not covered in the ICAM Handbook, but it became important in the global discussions due to the current process of global warming. This indicator can be adopted by countries with permanent ice cover (permafrost) in order to contribute to the evaluation of the overall effect of global warming.

REDESA and ILAC have an indicator to monitor the surface of protected marine-coastal areas. REDESA includes the surface of marine-coastal areas as an absolute measure, while ILAC includes as a percentage in relation to the total marine-coastal area. The ICAM Handbook considers this aspect in the evaluation section of the legislation for the ICZM. It is mentioned in this survey, since this aspect acquires paramount importance with the increasing development of economic activities in coastal and marine areas.

The protection of these areas becomes fundamental to ensure the preservation of important ecological sites (e.g., nesting and feeding areas, species migration routes, among others). 
Table 2 - Indicators related to the marine-coastal areas, included by the analyzed organizations.

Tabela 2 - Indicadores relacionados às áreas costeiras e marinhas, incluídos pelas organizações analisadas.

\begin{tabular}{|c|c|c|c|c|c|c|c|c|c|c|}
\hline Indicators & $\begin{array}{l}\Omega \\
\text { T1 } \\
0 \\
0 \\
0 \\
0 \\
0 \\
0 \\
0\end{array}$ & 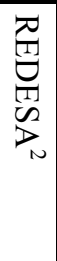 & $\begin{array}{l}F \\
\stackrel{7}{2} \\
D_{\omega}\end{array}$ & 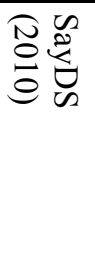 & 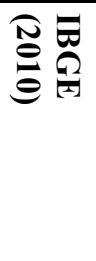 & 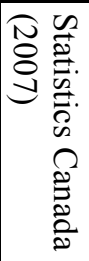 & 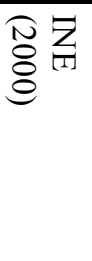 & $\begin{array}{l}\widehat{N} \Xi \\
\varrho \\
\varrho\end{array}$ & 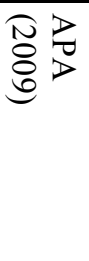 & 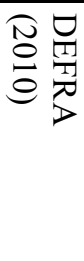 \\
\hline Total indicators & 3 & 5 & 1 & 2 & 3 & 1 & 3 & 2 & 2 & 1 \\
\hline Population growth in coastal areas & & & & & & & & $\mathbf{x}$ & & \\
\hline Population residing in coastal areas & & & & & $\mathbf{x}$ & & & & & \\
\hline Swimming suitability & & & & & $\mathbf{x}$ & & & & & \\
\hline Changes in glacial mass & $\mathbf{x}$ & & & & & & & & & \\
\hline $\begin{array}{l}\text { Load of total phosphorus estimated from the main direct } \\
\text { point sources (marine and continental) }\end{array}$ & & & & & & $\mathbf{x}$ & & & & \\
\hline Level of mercury in fish and shellfish & & & & & & & $\mathbf{x}$ & & & \\
\hline $\begin{array}{l}\text { Percentage of protected coastal marine areas in relation to } \\
\text { total coastal marine areas }\end{array}$ & & & $\mathbf{x}$ & & & & & & & \\
\hline Surface of protected marine areas & & $\mathbf{x}$ & & & & & & & & \\
\hline Total volume of aquaculture production & & $\mathbf{x}$ & & & & & & & & \\
\hline Biomass and reproductive biomass evolution & & & & $\mathbf{x}$ & & & & & & \\
\hline Spawning biomass and crayfish recruitment evolution & & & & & & & & & $\mathbf{x}$ & \\
\hline Spawning biomass and hake recruitment evolution & & & & & & & & & $\mathbf{x}$ & \\
\hline Number of vessels engaged in fishing & & $\mathbf{x}$ & & & & & $\mathbf{x}$ & & & \\
\hline Number of species with restrictions & & $\mathbf{x}$ & & & & & & & & \\
\hline Marine catches (fish, crustaceans and mollusks) & $\mathbf{x}$ & & & & & & & & & \\
\hline Depletion of world fish stocks & $\mathbf{x}$ & & & & & & & & & \\
\hline Fishing catches outside biosafety boundaries & & & & & & & $\mathbf{x}$ & & & \\
\hline Extraction of main/major fish & & $\mathbf{x}$ & & & & & & & & \\
\hline Maritime and continental fish production & & & & & $\mathbf{x}$ & & & & & \\
\hline $\begin{array}{l}\text { Relationship between maximum allowable catch and land- } \\
\text { ings }\end{array}$ & & & & $\mathbf{x}$ & & & & & & \\
\hline Fishing maximum sustainable yield & & & & & & & & $\mathbf{x}$ & & \\
\hline $\begin{array}{l}\text { Sustainability of fishing stocks in the country neighboring } \\
\text { areas }\end{array}$ & & & & & & & & & & $\mathbf{x}$ \\
\hline
\end{tabular}

${ }^{1}$ GEO Data Portal/ GEO Core Indicators (http://geodata.grid.unep.ch/extras/indicators.php);

${ }^{2}$ CEPALSTAT (http://websie.eclac.cl/sisgen/ConsultaIntegrada.asp?IdAplicacion=1); ${ }^{3} \mathrm{UNEP}(2005)$.

REDESA and the Brazilian IBGE presents indicators related to the aquaculture activity. REDESA includes the "Total aquaculture production" and IBGE presents "Marine and continental fish production". There is a pressing need to develop indicators, which monitor the quality of aquaculture because, when poorly managed, this type of activity can result in severe environmental damage, such as eutrophication of water bodies, siltation, and introduction of invasive species.
The array of all the indicators of these sources are fully described in Souto (2011). Below, the list of the key results acquired in the present work resumes the key points observed.

\section{Key results}

(1) The systems (or lists) of sustainability (or sustainable development) indicators, maintained by the analyzed sources, national or multinational, still need to 
improve the participation of the indicators related to marine-coastal areas;

(2) Some of the gaps identified in this work could be considered, in order to promote the rational use of marine-coastal living resources;

(3) The level of participation of indicators related to marine-coastal areas seems to be independent of the geographic localization of the country or its level of economic development;

(4) In a generally way, there is not also a maritime mentality in the analyzed official discussions and reports about sustainability (or sustainable development). This is a major shortcoming since the marine-coastal areas become increasingly important in the world scenario;

(5) ICAM Handbook must be better used by the researchers and the policy-makers, to improve the ICZM processes and to include more metrics related to marine-coastal areas;

(6) Only one of the schemes analyzed follows the systems approach. The Argentinian SayDS try to combine dimensions, in order to better understand its related aspects;

(7) The source with the highest total number of indicators (DEFRA) is the source with the lowest percentage of inclusion of marine-coastal indicators (about $0.8 \%$ ). The inverse situation occur with the source from Geo Project, which has the lowest total number of indicators, but presents the highest percentage of inclusion of marine-coastal indicators (about $14.3 \%)$.

\section{Conclusions}

The present work sheds light on some characteristics of the analyzed sustainability (or sustainable development) indicator systems (or lists), formulated by some of the most important national and multinational organizations worldwide. The ecological indicators list presented in the ICAM Handbook was used as a reference to the reanalyses of the selected sources, including official publications and websites.

The presented reanalysis is important to verify the level of coverage of the issues related to marine-coastal areas in national (or multinational) official reports on indicators of sustainability (or sustainable development). These areas are essential in the processes of formulation, implementation and maintenance of these lists (or systems) of indicators, in order to fully reach the sustainable development, which is based on the economic growth with environmental conservation and social equality.

The evaluated organizations have incipient coverage of relevant aspects to the marine-coastal areas, in a general way, which must be monitored to provide information to the ICZM process, in order to achieve the targets towards the sustainable development. The lack of such indicators hampers and probably prevents the development of management plans aimed at conservation of biological diversity and productivity in marine-coastal areas, part of the ICZM goals, as presented by GESAMP (2006).

In addition, most ecological indicators suggested in the ICAM Handbook are not included in the official publications and websites selected to this work. These indicators relate to important aspects regarding conservation of biological diversity and productivity of marinecoastal ecosystems. This can include, such critical factors as diversity of communities, populations, species or even genetic variability; abundance (in number and density) of marine organisms; trophic interactions; health and species distribution; habitat quality; and oceanographic characteristics (related to sedimentation, physical processes and system changes).

In Brazil, supervising many of these aspects still requires an institutional organization that enables parameter monitoring, in order to improve the knowledge of the Brazilian marine-coastal areas, regarding the ecological dimension of sustainability. So, will be possible to improve its sustainable development indicators list. The same institutional problem occur with others countries belonging the Latin America and Caribbean region. Martínez (2001) also cites the following challenges to the development of this type of list (or system) in this region: $i)$ the involved costs to keep it; ii) the insufficiently recognition of the importance of this type of list (or system) to the decision-making processes; iii) the methodological aspects and problems, since the sustainability (or the sustainable development) is a concept which still needs a worldwide accepted definition.

The environment is paramount within the ICZM process since it is the means to support life and fundamental to the development of economic activities. Given the size of the Brazilian coastal and maritime zones, and the diversity of natural resources in those waters, the monitoring of these aspects is of strategic importance for the country in the international relations background.

The marine-coastal areas shelters a notable diversity of mineral deposits, live resources, sources of energy, all of them important to any country's sovereignty. In the words of Moraes (2007, p.28, our translation): "Seaside, an unusual place, a rare and strategic localization".

Future researches on the institutional arrangements and legislation of countries, related to the marine-coastal areas, may reveal the reasons for the lack of information related to these areas in the official sources of sustainability indicators. 
In addition, the future examination of national legislation for the sustainability (or sustainable development) and for environmental issues in the countries, could provide other conclusions, regarding on the importance of the marine-coastal areas in the production of its official statistics and in the policy-making process. And could collaborate to confirm the results acquired in this work, of which the representation of the marine-coastal areas in the sustainability (or the sustainable development) indicators systems (or lists) seem to be independent of the economic development level and the geographic localization of the country.

This work aims at contributing to the improvement of the analyzed systems (or lists) of sustainability (or sustainable development) indicators, highlighting the international standards in this issue, as well as to alert researchers and policy-makers to the importance of the natural environment as essential to the support of life, of the conservation of biological diversity, and of the productivity in the marine-coastal areas.

\section{Appendix}

Supporting Information associated with this article is available on-line at http://www.aprh.pt/rgci/pdf/rgci535_Souto_Supporting-Information.pdf

\section{Acknowledgements}

I would like to dedicate special thanks to the following persons: Dr. João Alveirinho Dias (Professor at the University of Algarve, Portugal), the Editor-in-Chief of the Journal of Integrated Coastal Zone Management and other reviewers of the manuscript, with your suggestions and corrections. I also thank the Federal University of Rio de Janeiro and the National Council for Scientific and Technological Development of Brazil, to support this research.

A shorter version of the work described in this paper, before titled "The (sub) representation of coastal and marine areas of sustainability indicators for national and multinational", was presented orally at the Brazilian Congress of Oceanography, held in Rio de Janeiro in 2012, in order to analyze how the coastal and marine issues were included in the selected official sustainability (or sustainable development) indicator systems (or lists).

\section{References}

Asmus, M.L.; Kitzman, D.; Laydner, C.; Tagliani, C.R.A. (2006) Gestão Costeira no Brasil: instrumentos, fragilidades e potencialidades. Gestão Costeira Integrada (ISSN: 1677-4841), 4(5):5257. Available on-line at http://www.praia.log.furg.br/Publicacoes/2006/2006a.pdf

APA (2007) - Sistema de Indicadores de Desenvolvimento Sustentável: SIDS - Portugal. 351p. + Anexos, Agência Portuguesa do Ambiente (APA), Lisboa, Portugal. ISBN: 978-9728577407. Available on-line at http://www.apambiente.pt/_cms/view/page_doc. php?id=307

APA (2009) - SIDS Portugal: Indicadores Chave 2009. 70p., Agência Portuguesa do Ambiente (APA), Lisboa, Portugal. ISBN: 978-9728577483. Available on-line at http://www.ine.pt/ngt_server/ attachfileu.jsp?look_parentBoui=143210193\&att_display=n\&att_download=y

Bertalanffy, L. von (2006) - Teoria Geral dos Sistemas. Fundamentos, desenvolvimento e aplicações. 2.ed.; 360p.,
Editora Vozes, Petrópolis, Rio de Janeiro, RJ, Brasil. ISBN: 978-8532636904.

CEPAL (2001) - Informe del Seminario Indicadores de Desarrollo Sostenible em América Latina y el Caribe. 30p., Comisión Económica para América Latina y el Caribe (CEPAL), Naciones Unidas, Santiago do Chile, Chile. Available on-line at http://www.cepal.org/dmaah/publicaciones/xml/4/10084/lcr2077e.pdf

CEPAL (2002) - La sostenibilidad del desarrollo en América Latina y el Caribe: desafios y oportunidades. 251p., Naciones Unidas, Comisión Económica para América Latina y el Caribe (CEPAL), Santiago de Chile, Chile. ISBN: 9213220235.

Cheong, S.-M. (2008) - A new direction in coastal management. Marine Policy (ISSN: 0308-597X), 32(6):1090-1093. DOI: 10.1016/j.marpol.2008.03.004

Christofoletti, A. (2010) - Modelagem de sistemas ambientais. 5.ed., 236p., Editora Blucher, São Paulo, Brasil. ISBN: 9788521201779 .

EC (2001) - A Sustainable Europe for a Better World: A European Union Strategy for Sustainable Development (Commission's proposal to the Gothenburg European Council) 17p., Commission of the European Communities, Brussels, Belgium. Available on-line at http://eur-lex.europa.eu/legal-content/EN/TXT/PDF/?uri= CELEX:52001DC0264\& from=EN

Cooper, J.A.G. (2011) - Progress in Integrated Coastal Zone Management (ICZM) in Northern Ireland. Marine Policy, 35(6):794-799. DOI: 10.1016/j.marpol.2011.01.002

DEFRA - Department for Environment, Food and Rural Affairs (2010) - Measuring Progress: Sustainable Development Indicators 2010. 140p., Department for Environment, Food and Rural Affairs, London, England. Available on-line at http://archive.defra.gov.uk/sustainable/government/progress/documents/ SDI2010_001.pdf

Gallagher, A. (2010) - The coastal sustainability standard: A management systems approach to ICZM. Ocean \& Coastal Management, 53(7):336-349. DOI: 10.1016/j.ocecoaman.2010. 04.017

Gallopín, G. (2003) - A systems approach to sustainability and sustainable development. 42p., United Nations, Sustainable Development and Human Settlements Division, ECLAC Serie medio ambient y desarrollo 64, United Nations, Santiago de Chile, Chile. ISBN: 9211213983. Available on-line at http://repositorio. cepal.org/bitstream/handle/11362/5759/S033119_en.pdf?sequence $=1$

GESAMP (1996) - The contributions of science to coastal zone management. 66p., GESAMP - IMO/FAO/UNESCOIOC/WMO/IAEA/UN/UNEP Joint Group of Experts on the Scientific Aspects of Marine Environmental Protection, United Nations, Food and Agriculture Organization, GESAMP Reports and Studies 61, Rome, Italy. ISBN: 9251038562. Available online at http://www.fao.org/3/contents/dc824e26-b1b7-568d-87701f9347ecb063/W1639E00.HTM

IBGE (2010) - Indicadores de Desenvolvimento Sustentável: Brasil 2010. 443p., Instituto Brasileiro de Geografia e Estatística (IGBE), Rio de Janeiro, RJ, Brazil. ISBN: 978-8524041334.

INE (2008) - Desarrollo Sostenible 2008: Principales Indicadores de España para el Seguimento de la Estrategia de DS de la UE. 112p., Instituto Nacional de Estadística (INE), Madrid, Spain. ISBN: 978-8426037558.

INEGI (2000) - Indicadores de Desarrollo Sustentable de México. 213p., Instituto Nacional de Estadística, Geografía e Informática (INEGI) México. ISBN: 9701330153.

IOC (2006) - A Handbook for Measuring the Progress and Outcomes of Integrated Coastal and Ocean Management. 224p., The United Nations Educational, Scientific and Cultural Organization, Intergovernmental Oceanographic Comission (IOC), Paris, France. Available on-line at http://unesdoc.unesco.org/images/ 0014/001473/147313e.pdf 